\title{
Analysis of Land Cover Change of Lake Rawapening with Sentinel 1 - Synthetic Aperture Radar Data
}

\author{
Lalu Muhamad Jaelani ${ }^{1}$, Rizky Annisa Putri ${ }^{1}$ \\ ${ }^{I}$ Dept. of Geomatics Engineering, Institut Teknologi Sepuluh Nopember, Surabaya, Indonesia- 60111 \\ *Corresponding author: Lmjaelani@geodesy.its.ac.id
}

\begin{abstract}
Approximately $90 \%$ of freshwater on the earth surface is stored by lakes and reservoirs that provide benefits for human life such as for daily water needed, industry, agriculture, transportation, hydroelectric power and tourism. Most watersheds (DAS) and lakes in Indonesia have experienced the quality and quantity degradation caused by population growth, land conversion and erosion. Lake Rawapening in Central Java is one of fifteen Indonesian National Priority Lakes that should be seriously monitored and well managed. For routine monitoring of land cover change of the lake and its watershed, an optical remote sensing data that generally used was facing a problem related to cloud cover over the area of lake. In this research, we propose the utilization of Sentinel $1 \mathrm{~A}$, an active RADAR remote sensing data which can penetrate the cloud, thus more effective for observing land cover changes. The classification result of December 2016 data has strong relationship with field object $($ Kappa $=94.218 \%)$. All water objects were recognized as water, $94.595 \%$ of wetland were recognized as wetland (others as water), $91.379 \%$ of vegetation were recognized as vegetation (others as agriculture), $\mathbf{9 5 . 2 3 8 \%}$ of agriculture were recognized as agriculture (others as urban) and $\mathbf{9 6 . 7 7 4 \%}$ of urban were recognized as urban (others as wetland and agriculture). During May and December 2016, the landcover change was triggered by high precipitation in December and rapid-uncontrolled growth of water hyacinth in May. During May and December 2016, the landcover change was triggered by high precipitation in December and rapid-uncontrolled growth of water hyacinth in May.
\end{abstract}

Keywords-Lake Ecosystem Monitoring, Satellite Data, Active Remote Sensing

\section{INTRODUCTION}

$\mathrm{L}$ akes play important roles as freshwater resources for drinking water, agriculture, industry, fishing, recreation, and tourism [1]. Most of fresh water on the earth surface is stored by lakes and reservoirs that provide benefits for human life. Based on a report released by the Ministry of Environment (KLH) of Indonesia , watersheds and lakes ecosystems in Indonesia contain $25 \%$ of the world's germplasm, supplying $72 \%$ of surface water and water providers for agriculture, community water resources, agriculture, hydroelectric power, tourism and others[2]

Water catchment area of lake needs to have at least $30 \%$ of forest area with controlled erosion and sediment rate. However, most of lakes in Indonesia are suffering from several damages that needs to be saved[3]. The decrease of lake quality is mainly caused by population growth, pollution, erosion and land conversion. The conversion of forests in the area around lake into residential areas, plantations, agriculture, recreation and road infrastructure will cause soil erosion during the rainy season and reduce the catchment area. This condition will change a lake as an aquatic ecosystem to the form of the terrestrial ecosystem [4].

Based on the National Conference of Lake in Indonesia hold in 2009, there are 15 lakes priorities that increasingly threatened due to damage and environmental pollution in water catchment area. Lake Toba, Lake Maninjau, Lake Singkarak, Lake Sentani, Rawa Lake, Lake Batur, and Lake Rawa Pening, Lake
Toba, Lake Matano and Lake Mahakam (Semayang, Jempang, Melintang) was listed as lakes priorities [3].

Lake Rawapening is one of lake priorities located in Central Java. Lake Rawapening plays as a source of life for local community indicated by their various daily activities are conducted in Lake Rawapening and its watershed[5]. The degradation of lake function was triggered by land conversion at water catchment area into settlement and agriculture field especially in Kebumen, Tegaron and Sepakung.

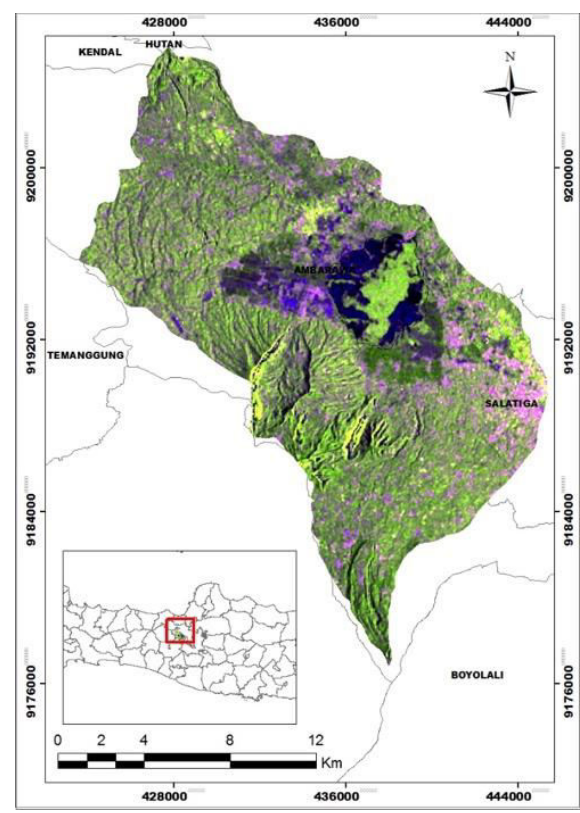

Figure 1. Study Area: Lake Rawapening 
According to the Ministry of Environment report in 2010, Lake Rawapening has undergone many ecologically changes that can be seen from uncontrolled water weeds, even in the dry season it can cover the surface of the lake up to $70 \%$ and decrease lake water volume by $29.34 \%$ over a period of 22 Year (1976 1998). The presence of water hyacinth or weeds in large quantities that covered the surface of waters will reduce the light penetration into water, reduce oxygen dissolved in water, then reduce aquatic animals. This also has negative effects to fishermen income [6]. If the amount of water hyacinth couldnot be controlled, it is estimated that by 2021 water ecosystem in Lake Rawapening will be totally transformed into a land ecosystem [7].

In order to monitor the land cover change over Lake Ecosystem, an efficient method such as remote sensing technique can be utilized. To reduce the cloud cover disruption encountered when using optical satellite imagery, the Synthetic Aperture Radar (SAR) data can be utilized. This SAR data can penetrate the cloud, then more effective to observe land cover change in the tropical region [8].

The European Space Agency (ESA) launched one of the constellation of two radar satellite Sentinel-1A in April 2014. Sentinel satellite provides C-band images in both singular and dual polarization within 12 days of repeated cycle. The data is free of charge for all users which makes it more attractive for new challenging applications and opportunities [9]. It can acquires images in three acquisition modes as Stripmap (SM), Interferometric Wide Swath (IW), Extra Wide Swath (EW) and Wave (WV) with different processing levels [10].

In this research We evaluate the land cover changes of Lake Rawapening area using Sentinel-1A Level-1 Ground Range Detected High-resolution (GRDH) products acuired on May 8, 2016 and December 10, 2016

\section{METHOD}

\section{A. Data}

In this research, 4 Sentinel-1 data recorded in 2015 and 2016 were used. The data was grouped into two different sessions as presented in Table 1.

Table 1. Data

\begin{tabular}{|c|c|c|c|}
\hline No & ID_Scene & $\begin{array}{c}\text { Acquisition } \\
\text { Date }\end{array}$ & Season \\
\hline 1 & $\begin{array}{l}\text { S1A_IW_GRDH_1SDV } \\
\text { 20150514T221659_201 } \\
\text { 50514T221735_005923_0 } \\
\text { 07A15_D752 }\end{array}$ & $\begin{array}{c}14 \text { May } \\
2015\end{array}$ & dry \\
\hline 2 & $\begin{array}{l}\text { S1A_IW_GRDH_1SDV } \\
\text { 20151216T221659_201 } \\
\text { 51216T221734_009073_0 } \\
\text { 0D07E_0199 }\end{array}$ & $\begin{array}{c}16 \\
\text { December } \\
2015\end{array}$ & $\begin{array}{l}\text { Wet/ } \\
\text { rainy }\end{array}$ \\
\hline 3 & $\begin{array}{l}\text { S1A_IW_GRDH_1SDV } \\
\text { 20160508T221700_201 } \\
\text { 60508T221735_011173_0 } \\
\text { 10DF3_9F01 }\end{array}$ & 8 May 2016 & dry \\
\hline 4 & $\begin{array}{l}\text { S1A_IW_GRDH_1SDV } \\
\text {-20161210T221709_201 } \\
\text { 61210T221744_014323_0 }\end{array}$ & $\begin{array}{c}10 \\
\text { December } \\
2016 \\
\end{array}$ & $\begin{array}{l}\text { Wet/ } \\
\text { rainy }\end{array}$ \\
\hline
\end{tabular}

1731A_360F

\section{B. Pre-processing}

Pre-processing Sentinel-1 (Level 1, GRDH) data was performed using Sentinel-1 Toolbox (S1Tbx) software. The initial process involved applying orbit correction to update the orbital file in the metadata, to provide accurate position and satellite speed.Then, radiometric calibration was performed to produce sigma nought value $\left(\sigma^{\circ}\right)$. In order to reduce the speckle effect of SAR image, a speckle filtering with $5 \times 5$ gamma map was done. If Sentinel-1A image was in reverse position, then geometric distortion need to be corrected by applying an geometric correction with Doppler Range Terrain Correction. The Digital Number (DN) value of the SAR data was converted to the backscatter value in decibels (db). Some of these corrections were useful for reducing topographic effects but resulting a different slope correction effects. Here, the slope correction model from Kellndorfer et. al. was used to correct the slope effects (1998) [11]

$\sigma_{c}^{\circ}=\sigma^{\circ} \frac{\sin \varphi}{\sin \theta}$

$\sigma_{c}^{\circ}$ is backscatter coefficient of SAR after calibration, $\sigma^{\circ}$ is original backsctatter coefficient of SAR, $\varphi$ is Local Incidence Angle, and $\theta$ is SAR Incidence Angle at the center of image [12]. Digital Number (DN) data was converted into backscatter in decibel (db). After slope normalization, a vector data was used to subset area of study. All of data then exported into KMZ format to overlaid in Google Earth.

\section{Image Classification}

For image classification, a Semi-Automatic Classification Plugin (SCP) on QGIS software was used. This plugin provides some tools for classification processing and raster calculation. SAR data was analyzed based on RGB color system, where VV, VH and VV/VH assigned as Red, Green and Blue, respectively.

\section{Accuracy assessment}

Accuracy assessment was performed for classified image and 'field' object using following kappa coefficient formula [13]

$\operatorname{Kappa}(k)=\frac{N \sum_{i}^{r} X_{i i}-\sum_{i}^{r} X_{i+} X_{+i}}{N^{2}-\sum_{i}^{r} X_{i+} X_{+i}} \times 100 \%$

$K$ is Kappa Coefficient, $\sum_{i=1}^{I} \pi_{i i}$ is the total proportion of main diagonal of observation frequency and $\sum_{i=1}^{I} \pi_{i+} \pi_{+i}$ is total major marginal proportion of observation frequency. Kappa analysis tool follows the rule of Kappa $<0.20$ as low correlation; $0.21-0.40$ is Fair; 0.41-0.60 is enough, 0.61-0.80 is strong and 0.811.00 is very strong [14] 


\section{E. Area Calculation}

After performing the accuracy assessment, the final step was to calculate the area of each object class to analyze the land cover change within the time range of May 2016 and December 2016.

\section{RESULTS AND DISCUSSION}

Sentinel-1A with polarization of VV, VH, and VV / VH have been classified into 5 classes ie water, wetlands, agriculture, vegetation and urban. The classification result was presented in Figure 2. Accuracy of classification results with supervised methods produced overall accuracy of $96.417 \%$ and Kappa accuracy of 0.954 . The kappa accuracy was in the range of strong correlation between classified object and field object.
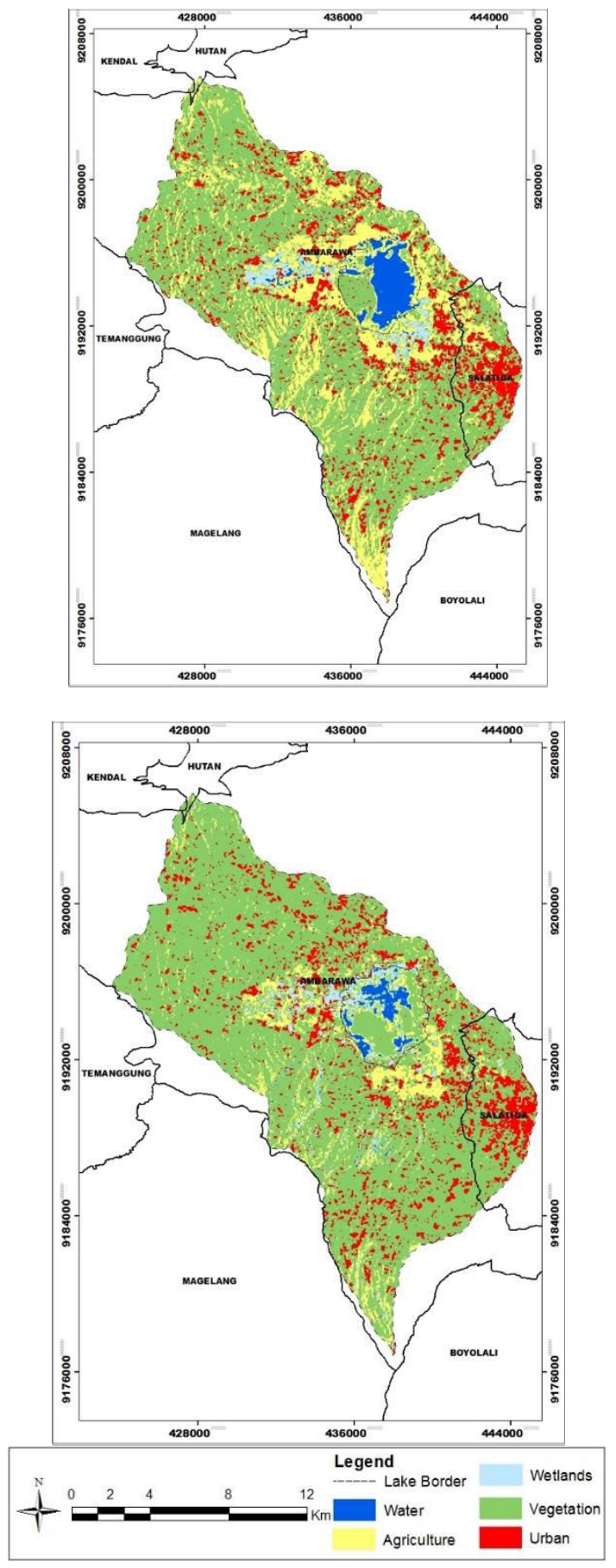

Figure 2. Landcover classification: 14 May 2015 (top) 16 December 2015 (bottom)
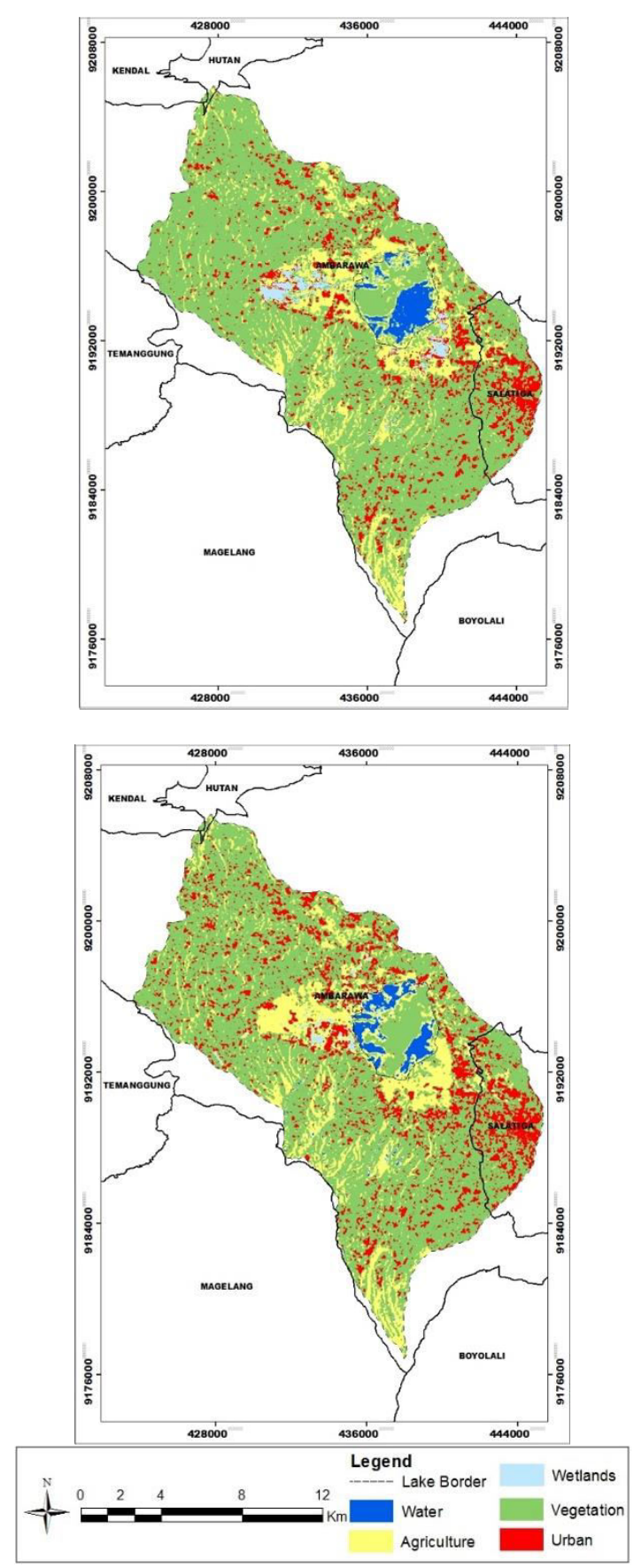

Figure 3. Landcover classification: 8 May 2016 (top) 10 December 2016 (bottom)

Table 2. Area of Classified Object

\begin{tabular}{ccccc}
\hline \multirow{2}{*}{ Class } & \multicolumn{2}{c}{ Area (ha) 2015} & \multicolumn{2}{c}{ Area (ha) 2016} \\
\cline { 2 - 5 } & May & December & May & December \\
\hline Water & 903.449 & 341.427 & 650.199 & 437.495 \\
Agriculture & 5947.993 & 2281.351 & 5878.058 & 2252.789 \\
Wetlands & 511.777 & 845.290 & 313.889 & 409.849 \\
Vegetation & 16783.044 & 20675.005 & 17299.961 & 21040.292
\end{tabular}




$\begin{array}{ccccc}\text { Urban } & 3358.285 & 3361.475 & 3362.441 & 3364.123 \\ \text { Total } & 27504.548 & 27504.548 & 27504.548 & 27544.548\end{array}$

After accuracy assessment, the area of each class of each classified sentinel data was calculated. The area of classified data was dominated by vegetation class following by urban, agriculture, water and wetland. As presented in Table 2 the largest water area occurred in May 2015 (903.449 ha) and May 2016 (650.199 ha) compared to in December 2015 and December 2016. This was because during May 2015 and 2016 before Sentinel-1A SAR data was recorded, there were routine activities of cleaning water plants in Rawapening lake by local people.

Table 3. Confussion Matrix of Sentinel 1A Classification

\begin{tabular}{cccccccc}
\hline \multirow{3}{*}{ Classification } & \multicolumn{8}{c}{ Reference } & $\begin{array}{c}\text { No. } \\
\text { of } \\
\text { Row }\end{array}$ & $\begin{array}{c}\text { User's } \\
\text { Accuracy } \\
(\%)\end{array}$ \\
\cline { 2 - 9 } & A & B & C & D & E & & \\
\hline $\mathrm{A}$ & 41 & 0 & 0 & 0 & 0 & 41 & 100.00 \\
$\mathrm{~B}$ & 0 & 40 & 0 & 2 & 0 & 42 & 95.238 \\
$\mathrm{C}$ & 2 & 0 & 35 & 0 & 0 & 37 & 94.595 \\
$\mathrm{D}$ & 2 & 3 & 0 & 53 & 0 & 58 & 91.379 \\
$\mathrm{E}$ & 0 & 2 & 0 & 0 & 60 & 62 & 96.774 \\
\hline No. of & 45 & 45 & 35 & 55 & 60 & 240 \\
Column & \multicolumn{7}{c}{ Kappa (k)=94.218\% } \\
\hline \multicolumn{8}{c}{ Overall accuracy $=95.417 \%$} \\
\hline
\end{tabular}

$\mathrm{A}, \mathrm{B}, \mathrm{C}, \mathrm{D}, \mathrm{E}$ is water, agriculture, wet land, vegetation and urban areas, respectively.

The convolution matrix was presented to analyzed the accuracy of each class of classification. As presented in Table 3, all data was classified into 5 classes: water, wetland, vegetation, agriculture and urban. In the data of December 2016, there was $100 \%$ of water object which recognized as water, $94.595 \%$ of wetland were recognized as wetland (others as water), $91.379 \%$ of vegetation were recognized as vegetation (others as agriculture), $95.238 \%$ of agriculture were recognized as agriculture (others as urban) and $96.774 \%$ of urban were recognized as urban (others as wetland and agriculture). The area of agriculture decreased by 3666.642 ha in December 2015 and by 3625.269 ha in December 2016. This phenomenon occurred because of agriculture area often flooded during the rainy season. This was also accompanied by the increasing of wetlands area during the rainy season about 333.513 ha in 2015 and 95.960 ha in 2016.

Vegetation area in rainy season (December) was 3891.961 ha and 3740.331 ha larger than in dry season (May) of 2015 and 2016. Meanwhile, urban area around the lake Rawapening continuously increased of 3.190 ha from May 2015 to December 2015, 0.966 ha from December 2015 to May 2016 and 1.682 ha in the period of May 2016 to December 2016.

\section{CONCLUSION}

We have processed remotely sensed data acquired by Sentinel 1 SAR sensor for land cover monitoring in Lake Rawapening and its watershed area. The classification result of December 2016 data has strong relationship with field object $($ Kappa $=94.218 \%)$. All water objects were recognized as water, $94.595 \%$ of wetland were recognized as wetland (others as water), $91.379 \%$ of vegetation were recognized as vegetation (others as agriculture), $95.238 \%$ of agriculture were recognized as agriculture (others as urban) and $96.774 \%$ of urban were recognized as urban (others as wetland and agriculture). During May and December 2016, the landcover change was triggered by high precipitation in December and a rapid-uncontrolled growth of water hyacinth in May.

\section{ACKNOWLEDGEMENT}

We thank to the Center for Earth, Disaster and Climate Change (PSKBPI) of Institut Teknologi Sepuluh Nopember for data support and guidance during this research.

\section{REFERENCES}

C. Giardino, M. Pepe, P. A. Brivio, P. Ghezzi, and E. Zilioli, "Detecting chlorophyll, Secchi disk depth and surface temperature in a sub-alpine lake using Landsat imagery," Sci. Total Environ., vol. 268, no. 1-3, pp. 19-29, Mar. 2001.

KLH, "Grand design Penyelamatan Ekosistem Danau Indonesia," Jakarta, 2012.

KLH, "Profil 15 Danau Prioritas Nasional," Kementrian Lingkung. Hidup, 2011.

V. A. Kumurur, "Aspek Strategis Pengelolaan Danau Tondano Secara Terpadu," EKOTON, vol. 2, no. 1, pp. 73-80, 2002. DAS RAWAPENING (' Study of Land Use Change Suitability Againts Area Function Directing In The Rawapening Sub Watershed ') PENDAHULUAN Danau adalah genangan air dalam suatu cekungan permukaan tanah yang terbentuk secara alami maupun buat," vol. 3, no. 4, pp. 958-967, 2013.

[6] E. L. Gutierrez, E. F. Ruiz, E. G. Uribe, and J. M. Martinez, "Biomass and productivity of Water hyacinth and their application in control programs. Biological and Integrated Control of Water Hyacinth, Eichhornia crassipes," vol. 102, pp. 109-199, 2001.

S. Tri Retnaningsih, T. Shalihuddin Djalal, Sutikno, S Hadisusanto, and P. Gell, "Strategi Diatom Danau Rawapening: Kajian Paleolimnologi sebagai Landasan Pengelolaan Danau," Pros. Semin. Nas. Limnol. V tahun 2010, pp. 102-115, 2012.

[8] H. Balzter, B. Cole, C. Thiel, and C. Schmullius, "Mapping CORINE land cover from Sentinel-1A SAR and SRTM digital elevation model data using random forests," Remote Sens., vol. 7, no. 11, pp. 1487614898, 2015.

[9] T. Nagler, H. Rott, M. Hetzenecker, J. Wuite, and P. Potin, "The Sentinel-1 Mission: New Opportunities for Ice Sheet Observations," Remote Sens., vol. 7, no. 7, pp. 9371-9389, 2015.

[10] S. Abdikan, F. B. Sanli, M. Ustuner, and F. Calò, "Land Cover Mapping Using Sentinel-1 Sar Data," ISPRS - Int. Arch. Photogramm. Remote Sens. Spat. Inf. Sci., vol. XLI, no. July, pp. 757-761, 2016.

[11] J. Kellndorfer, L. E. Pierce, M. C. Dobson, and F. T. Ulaby, "Toward Consistent Regional-to-Global-Scale Vegetation Characterization Using Orbital SAR Systems," Geosci. Remote Sens, vol. 36, no. 5, pp. 1396-1411, 1998.

[12] Z. Zhou et al., "Terrain Slope Correction and Precise Registration of SAR Data for Forest Mapping and 
Monitoring," Proc. Int. Symp. Remote Sens. Env., no. Figure 1, pp. 1-4, 2011.

[13] R. M. Sampurno and A. Thoriq, "KLASIFIKASI Tutupan Lahan Menggunakan Citra Landsat 8 Operational Land Imager (Oli) Di Kabupaten Sumedang," vol. 10, no. 2, 2016.

[14] B. Murti, "Variabel dan Reliabilitas Pengukuran," pp. $1-19,2011$.
[15] Abimanyu, K. Analisis pemanfaatan sumber daya alam danau rawa pening kabupaten semarang skripsi.2016

[16] Di Falco, S., Bezabih, M., \& Yesuf, M. Seeds for livelihood: Crop biodiversity and food production in Ethiopia. Ecological Economics, 69(8), 1695-1702. https://doi.org/10.1016/j.ecolecon.2010.03.024.2010 